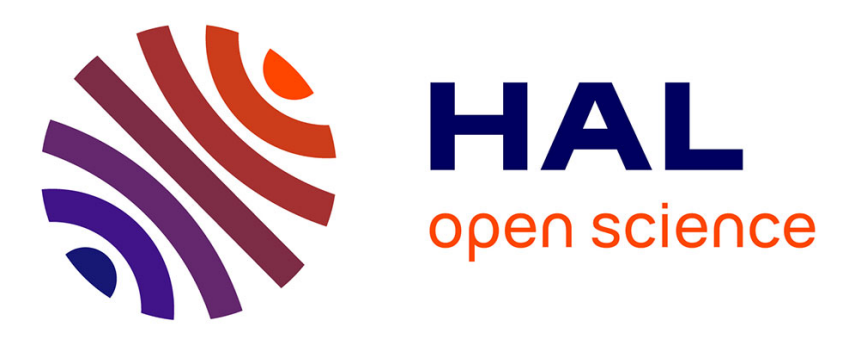

\title{
The coral trade in Smyrna at the end of the 17th century perceived through several of François Garnier's business deals
}

Olivier Raveux

\section{- To cite this version:}

Olivier Raveux. The coral trade in Smyrna at the end of the 17th century perceived through several of François Garnier's business deals. Rives Méditerranéennes, 2019, Au coeur des mutations du négoce en Méditerranée. Les acteurs et leurs choix. Smyrne, XVIIe-XXe siècle, 59, p.135-151. 10.4000/rives.7026 . halshs-02368748

\section{HAL Id: halshs-02368748 \\ https://shs.hal.science/halshs-02368748}

Submitted on 18 Nov 2019

HAL is a multi-disciplinary open access archive for the deposit and dissemination of scientific research documents, whether they are published or not. The documents may come from teaching and research institutions in France or abroad, or from public or private research centers.
L'archive ouverte pluridisciplinaire HAL, est destinée au dépôt et à la diffusion de documents scientifiques de niveau recherche, publiés ou non, émanant des établissements d'enseignement et de recherche français ou étrangers, des laboratoires publics ou privés. 


\title{
The coral trade in Smyrna at the end of the 17th century perceived through several of François Garnier's business deals
}

\author{
Olivier Raveux \\ CNRS, Aix Marseille univ, UMR TELEMMe, Aix-en-Provence, France
}

\begin{abstract}
By focusing on several sales of Mediterranean red coral beads that the Marseilles merchant François Garnier and his commission agent François Tiran made in Smyrna around 1680, this paper brings an insight into Eurasian trade during the early modern period, and the variety of links and means that were employed to circulate the goods involved. Moreover, it helped us understand the specific mechanisms of commercial activity in the main Levant port towards the end of the $17^{\text {th }}$ century and to identify the roles and actions of the men in charge of this trade. Using Smyrna as a 'laboratory', this research focused on the exportation of Mediterranean red coral to Asia, thus giving us a deeper understanding of the traders' practices and intricate workings of exchange, but more specifically on the work of the Marseilles and Armenian traders in a difficult commercial niche, which in fact generated good profits when the products were of high quality and the market had been well-studied.
\end{abstract}

Keywords : coral, trade, Marseilles, Levant, Smyrna

\section{Résumé}

Le commerce du corail à Smyrne à la fin du XVII ${ }^{\mathrm{e}}$ siècle à travers quelques ventes de François Garnier

L'analyse de quelques ventes de grains de corail rouge de Méditerranée du marchand marseillais François Garnier et de son commissionnaire François Tiran à Smyrne autour de l'année 1680 permet d'entrevoir la variété des maillons et des moyens de la circulation des marchandises dans le commerce eurasiatique de l'époque moderne. Elle donne également la possibilité de saisir les ressorts précis de l'activité commerciale dans la principale échelle levantine du XVII siècle finissant et de cerner les capacités d'action des hommes qui en ont la charge. À travers le laboratoire smyrniote et une immersion dans la filière d'exportation du corail vers l'Asie, cette recherche a pour objectif d'approcher au plus près les acteurs du négoce, d'examiner leurs pratiques marchandes et les rouages complexes de l'échange. Cette contribution se penche notamment sur le travail des négociants marseillais et arméniens dans une niche commerciale difficile, mais apportant de confortables bénéfices quand les produits sont de qualité et les caractéristiques du marché bien analysées.

Mots-clés : corail, commerce, Marseille, Levant, Smyrne 
Baltic amber, Bahrain pearls, Mediterranean red coral... As commodities combining the appeal and preciousness of a rare and distant product, Neptune's treasures often played an important role in the intercontinental exchanges of the early modern period. However, although these commercial products were at the heart of trade in the early days of globalisation, they have not been the focus of many studies. If one examines the export of Mediterranean red coral to Asia, the major works in recent decades have focused above all on highlighting the role played by Jewish merchants, portraying their ability to set up intercultural business networks, and analysing their business activities via trans-oceanic trading ${ }^{1}$. This focus of research on a commercial group and on the Atlantic has led to a certain amnesia on the subject, in particular on the permanence of the old coral route to Asia, which linked the European ports of the western Mediterranean basin to the Ports of the Levant and, overland by caravan to Persia, the Indian Ocean, and Tibet ${ }^{2}$.

The purpose of this article is to highlight the history of this ancient route during the early modern period through examining how trade was conducted in one of its main areas, Smyrna. It will consist of a time-bound case study, focusing on various sales carried out by a Marseilles coral merchant, François Garnier, and his commission agent, François Tiran, in Smyrna at the end of the 17th century. Based on the examination of notarial deeds and some of the correspondence between the two men around 1680, this research will seek to reveal the characteristics and challenges of exporting coral to Asia through the Ports of the Levant. Moving beyond the perceived resistance of the Mediterranean route due to Atlantic competition, this study aims above all to show the diversity of those involved in the global circulation of goods during the early modern period. Faced with large state-supported European companies and large community diaspora networks, "small" individual actors also managed to seize opportunities in the ongoing globalisation, while at the same time contributed to its construction, even though they were more often only links in chains whose end they could not see and which restricted their profits.

\section{Marseilles-Smyrna: a segment of the Eurasian coral trade}

While exporting Mediterranean coral to Asia was not new during the early modern period, the movement gained amplitude in the 17th century. Routes began multiplying and shipments became more regular. Marseilles and the Ports of the Levant maintained their prominence in this trade, and Smyrna took over from

\footnotetext{
${ }^{1}$ Gedalia Yogev, Diamonds and Coral: Anglo Dutch Jews and Eighteenth-Century Trade, Leicester, Leicester University Press, 1978; Francesca Trivellato, The Familiarity of Strangers. The Sephardic Diaspora, Livorno and Cross-Cultural Trade in the Early Modern Period, New Haven, Yale University Press, 2009.

2 Jean-Paul Morel, Cecilia Rondi-Costanzo, Daniela Ugolini (eds.), Corallo di ieri, corallo di oggi, Bari, Edipuglia, 2000. With regard to the impact of trans-oceanic trade development on intraAsian caravan traffic, see Niels Steensgaard, Carracks, caravans and companies: the structural crisis in the European-Asian trade in the early 17th century, Copenhagen, Studentlitteratur, 1973 and the many debates that followed this publication.
} 
Aleppo and Alexandria as the most popular port. At the end of the 17th century, the Anatolian port became the major meeting place between Marseilles maritime business and intra-Asian caravan activity. Owing to their presence in Smyrna, the Phocaean city's merchants became part of the coral export routes to Persia, the Indian Ocean and Tibet.

\section{Coral, a commodity of Eurasian trade}

Corallium rubrum (Linnaeus, 1758) is a type of coral that is almost endemic within the Mediterranean region. It is well suited for polishing and incision work, it has a wide range of colours (from blood red to "angel skin"), and is easier to fish than other specimens, particularly Corallium japonicum. For these reasons, most of the corals sold in the world during the early modern period came from the western basin of the Mediterranean, and it was here that this marine resource was fished and transformed into essentially necklaces and rosaries of round beads (called grains or perles in French) or small olive-shaped beads (olivettes).

During the early modern period, while Mediterranean red coral was used as a trading article in slave traffic, it was above all a highly valued product in Eurasian exchanges. It was a commodity for sale, as well as a product to barter with; it was even sometimes used as a currency. Thus, coral was one of the few European articles that could be sold on the markets from the Ottoman Empire through to China, Persia, India and Tibet. By using this commodity, the English, French, Dutch and Portuguese reduced somewhat the pronounced deficit in their trade balance with the East. Those working for the English East India Company, stationed at trading posts in the Indian Ocean, liked to emphasise its importance, one example being from Surate in 1639: "coral is the most stable and vendible commodity that Europe produces",

So, what were the profits generated by this trade? During the 1670s and the 1680s, coral derived from the sea was traded at around 3 to 4 livres tournois the pound weight of Marseilles in the western Mediterranean basin ${ }^{4}$. In India, in 1696, the French sold raw coral for about fifteen livres tournois for the same weight ${ }^{5}$. To have a better understanding of this price gap, more information would be needed on both raw and manufactured goods at several points of sale, but these two figures already provide an insight into this commodity's importance for the West's trading accounts. The pressure exerted on the Mediterranean economy due to the importance of coral in Eurasian trade was intense and could be discerned by

\footnotetext{
${ }^{3}$ William Foster, The English Factories in India, 1637-1641, Oxford, Oxford University Press, 1912, p. 208.

${ }^{4}$ Bouches-du-Rhône Departmental Archives (now ADBdR), 372 E 84, fol. 206, notarial act of $14^{\text {th }}$ Feb, 1682 (purchase of the Marseilles merchant Jérôme Eydin) and 356 E 449, fol. 522, notarial act of $19^{\text {th }}$ March, 1673 (Compagnie du Bastion de France's purchase). The pound weight of Marseilles was worth 13 ounces or 388.51 grams.

${ }^{5}$ French National Overseas Archives (now ANOM), C 2 64, Martin's letter to Surate dated $25^{\text {th }}$ July, 1696. 11 rupees 12 pessas the Indian serre (419.57 grams). 2 rupees and 6 pessas were worth 1 piastre, or about 3 livres tournois.
} 
one sole fact: the price of coral in Liguria quadrupled between 1600 and $1700^{6}$. A few Italian cities were always present at the head of this export sector, with Genoa and Livorno becoming the most important at the end of the 17th century. Thus, only Marseilles was in a position to challenge somewhat this Ligurian-Tuscan domination.

The awakening of Marseilles within the coral sector

At the beginning of the 17th century, Marseilles held a prominent position within the international coral trade to Asia, at least as a source of supply. In the 1620s, the English East India Company's directors presented the area as "the principal market for that commodity" ". However, the following decades were impacted by a decline, largely due to the difficulties of exploiting the rich North African coralligenous deposits. Nevertheless, Marseilles regained fresh impetus during the last third of the 17th century, and by the end of the 1680s, 100 to 150 quintals weight of Marseilles (four to six tons) of raw coral were being unloaded onto the port's quays annually ${ }^{8}$. Most of the merchandise came from Catalonia and Provence, but especially North Africa, thanks to the reactivation of fishing in the Bastion de France in 1666 and the creation of the new Compagnie du cap Nègre in 1666, which restored the fishing of coral on the Tunisian coast, stopped back in $1635^{9}$.

Marseilles' return to the coral sector also benefited from a renewed local commercial momentum. The Phocaean port's influence extended beyond the Mediterranean to the Americas, and its fleet increased, as shown by the increase in its transport capacity, which rose from 3,582 tons in 1664 to 17,752 in $1686^{10}$. Trade in the Levant grew steadily, pushing further the integration of Marseilles into Eurasian trade. Nevertheless, although the city gained from its relations with Asia, the benefit of these exchanges was limited due to its merchants being unable to operate beyond the Ports of the Levant. The Marseilles commercial businesses stopped in Smyrna, Aleppo, and Constantinople, cities that connected East and West, where Marseilles merchants had to hand over their goods to the Ottoman, Armenian and Persian traders, who then took the goods across land. Regarding trade with Inner Asia, the Marseilles traders were but the first link, perceiving the final outlets only as a distant and inaccessible horizon. Nevertheless, this situation enabled a small group of Provençal manufacturers to enjoy a new period of

\footnotetext{
${ }^{6}$ Edoardo Grendi, I Cervo e la Republica. Il modello ligure di antico regime, Turin, G. Einaudi, 1993, p. 151.

${ }^{7}$ W. Noel Sainsbury, Calendar of State Papers, Colonial Series: East India, China and Japan, vol. 4: 1622-1624, London, 1878, p. 471.

8 «État général de toutes les marchandises dont on fait commerce à Marseille en la présente année 1688 (...) », in Jacques Savary des Bruslons, Dictionnaire universel de commerce, Paris, t. III, 1730, p. 326-471.

${ }^{9}$ Paul Masson, Histoire des établissements et du commerce français dans l'Afrique barbaresque (1560-1793), Paris, 1903, p. 147.

${ }^{10}$ Gilbert Buti, «La flotte de commerce et de pêche de la France méridionale à la fin du XVII ${ }^{\mathrm{e}}$ siècle », in Antoine Reffuveille (ed.), Tourville et les marines de son temps, Saint-Lô, Archives départementales de la Manche, 2003, p. 49-90.
} 
prosperity. "The whole of the Orient is filled with their necklaces and bracelets", wrote Joseph Pitton de Tournefort about coral and the Marseilles traders in $1700^{11}$. Although an obvious exaggeration, the Aix-en-Provence botanist's comment revealed how dynamic this sector was sustained by a few merchants who specialised in exporting these products to Aleppo and especially Smyrna.

\section{Smyrna: a redistribution gateway to Inner Asia}

During the 16th century, the traditional coral export routes through the Ottoman Empire mainly stopped at the ports of Aleppo, Alexandria and Cairo. However, the situation changed in the 17th century as the Egyptian route was used less and Smyrna took over from Aleppo. The reasons for the supremacy of the Anatolian port were complex, combining fiscal, legal, political, and religious $\operatorname{aspects}^{12}$.

Smyrna's rise to power began in the first half of the 17th century and intensified thereafter. Data from the $1670 \mathrm{~s}$ on merchandise exports to the Phocaean port show that it was the leading port at that time. With an annual average of 1,922,300 livres tournois, it alone accounted for $31.22 \%$ of the total value of products shipped by the Ports of the Levant ${ }^{13}$. Moreover, by 1682 , the Marseilles traders had their main trading colony there, with about 60 to 70 individuals settled there ${ }^{14}$. These men did business with the locals, as well as with the merchants who arrived by intra-Asian caravans from Isfahan. Every year, from February to October, after several months of travel, goods from the Indian Ocean and Persia were transported by camel to Smyrna ${ }^{15}$. The Anatolian port had become a major link between Asia and Europe, and among the exchanges of goods that animated the area, coral was indeed present. This commodity, together with piastres, was one of the elements that made up the cargo returning to Isfahan and then on to the Indian Ocean and Tibet. Thus, Asia not only amassed HispanicAmerican silver, but also Mediterranean red coral.

The Marseilles-Smyrna route was therefore vital for all Marseilles merchants involved in the coral trade. If the Phocaean traders were unable to reside in Smyrna then it was necessary for them to have an attentive representative or commission agent on whom they could rely. For this reason, they sought at worst an acquaintance, at best someone from the family. And François Garnier, the

\footnotetext{
${ }^{11}$ Joseph Pitton de Tournefort, Relation d'un voyage du Levant, Paris, 1717, I, p. 15.

12 Elena Frangakis-Syrett, The Commerce of Smyrna in the Eighteenth Century, 1700-1820, Athens, Centre For Asia Minor Studies, 1992; Edhem Eldem, Daniel Goffman, Bruce Masters The Ottoman City between East and West: Aleppo, Izmir, and Istanbul, New York, Cambridge University Press, 1999.

${ }^{13}$ Paul Masson, Histoire du commerce français dans le Levant au XVII siècle, Paris, 1906, table 15 (calculations using data from the years 1671-1680).

${ }^{14}$ French National Archives, CARAN, B III 205, « Mémoire donné par les échevins et députés du commerce de Marseille », 1682.

15 On Smyrna, see Le voyage à Smyrne. Un manuscrit d'Antoine Galland (1678), Paris, Chandeigne, 2000 and the Bibliothèque Nationale de France (now BNF), ms. fr. 7174, « Mémoire de Monsieur d'Ortières », 1686, fol. 158-180).
} 
Marseilles coral merchant, was no exception to the rule. From 1679 onwards, he was represented in Smyrna by François Tiran, his cousin by marriage.

\section{A merchant and his commission agent}

Around 1680, François Garnier had become an experienced coral merchant, relying on well-structured export and sales networks in which the circle of relatives and family played a key role. His representative-broker in Smyrna, François Tiran, was a little younger than he was, and had started his career in the Marseilles maritime business on board different ships and continued building it within a family environment and around trade in Smyrna.

François Garnier, a coral merchant from Marseilles

François Garnier, the son of Jacques, a local merchant, and Graci Ollive, was born in Cassis around $1630^{16}$. We do not know much about his years in Cassis, nor do we know much about his father's activities. Maybe the family was involved in the coral trade, but for the moment there is no way of affirming this. Nevertheless, François Garnier built his professional career in Marseilles, indicated in the registration of his marriage in 1653 to Lucresse Marrot, the daughter of a cotton master ${ }^{17}$, and it seems that his business went from strength to strength as from 1667, after the death of his first wife and a new marriage to Françoise Arnaud, daughter of a local merchant ${ }^{18}$. From then on, up until his death in 1686, he was fully involved in the coral trade, helped for a time by his two brothers Honoré and Jean, and then by his son, also named François. François Garnier didn't move much. He ran his business from his shop on the port, near "la Loge" (the Chamber of Commerce) and his coral-trading colleagues, Jérôme Eydin, the Sallade brothers, and François Meistre.

The range of his activities seemed to focus on the commercial sphere. None of the approximately 80 documents found in the Marseilles notaries' archives concerning him indicate any involvement, even if only on an occasional basis, in fishing. Manufacturing however, is still somewhat of a mystery, although a notarial act indeed mentions Garnier's recruiting of a Catalan coral worker apprentice in May $1672^{19}$. Thus, he undoubtedly manufactured for a time, but he has never been presented as a coral manufacturer. For most of his career, François Garnier bought the goods he sold. But to whom exactly? To Genoese manufacturers perhaps ${ }^{20}$, to coral producers from Marseilles undoubtedly, and to

\footnotetext{
${ }^{16}$ ADBdR, Marseilles Parish registers, Saint-Martin, marriage Garnier-Marrot, 6th Sept. 1653.

${ }_{17}$ ADBdR, 357 E 144, fol. $987 \mathrm{v}^{\circ}$, marriage contract dated 7th Sept 1653.

${ }^{18}$ ADBdR, 372 E 69, fol. 2.232, marriage contract dated 12th Dec 1666.

${ }^{19}$ Joan Costa, from Cap de Creus on the Costa Brava (ADBdR, 359 E 120, fol. 401, apprenticeship contract dated 27th May 1672).

${ }^{20}$ The Chevalier d'Arvieux noted these purchases by the Marseilles merchants in Genoa in 1676 (BNF, ms. fr. 7.164, «Mémoire contenant l'état présent du commerce des nations française, anglaise, vénitienne, et hollandaise, dans la ville d'Alep »).
} 
his brother Honoré most certainly, when the latter returned to the family environment in Cassis in 1673 to open a coral workshop there.

So, in which markets did Garnier do business? One thing is clear when it comes to archival documents: his exports were closely linked to the area and networks through which Marseilles trade was carried out. His goods were dispatched on Phocaean vessels and were essentially delivered throughout the Mediterranean area, as well as to a few areas in the Atlantic not far from the Straits of Gibraltar. Thus, François Garnier's corals were sold mainly in Aleppo, Smyrna, Candia, Alexandria, Tripoly of Barbary, Rabat, Mogador, Cadiz, and Lisbon before continuing their journey to more distant destinations. This merchant from Marseilles was not part of the appropriate networks that would have enabled him to send his coral directly to Persia, the Indian Ocean, Tibet, and China.

François Garnier used various sales methods: shipping small quantities to Barbary as part of the bottomry loan; delegating power to a brother who travelled with the goods when it was necessary to have large volumes in Lisbon and Cadiz on the eve of departures to the West and East Indies; and finally through the representatives-commission agents in the Ports of the Levant who looked after regular dispatches and shipments of varying importance. François Tiran was in charge of this latter system in Smyrna.

François Tiran, a commission agent from the inner circle

Born in Marseilles around 1645, François Tiran was Lucresse Ailhaud's son and thus François Garnier's cousin by marriage ${ }^{21}$. His father Guillaume was a merchant who specialised in trading with the Levant, especially with Smyrna, and on whose route he died in $1670^{22}$. Tiran had been trained in business activities in the 1660s. He was the supercargo on board the ships of which his family and associates were joint owners, and particularly those ordered by the Toulon captain Pierre Serry, which sailed to Smyrna: La Flute Royale (1667), L'Espérance (1667-1668), and Le Saint-Cyprien (1669). With 90 crew members and weighing 600 tons, this last ship was once the largest commercial vessel on the Provençal coast $^{23}$.

After his marriage to Marguerite Beaumond, daughter of Pierre, a "bourgeoismerchant of Marseilles", in August $1669^{24}$, and the death of his father, he became a merchant in his own right and worked with his brother Jean and the Rampals, a family to whom he was very close. By 1680, the business links that the Tirans had with François Garnier were already well-established. The coral merchant invested in François Tiran's shipping trade to $\operatorname{Smyrna}^{25}$ and it is highly likely that his

\footnotetext{
${ }^{21}$ His mother, Françoise Ailhaud, was François Garnier's second mother-in-law's sister.

${ }^{22}$ ADBdR, 2 B 804, Guillaume Tiran's post-death inventory, 13th Jan, 1671.

${ }^{23}$ The Dunkirk Chamber of Commerce and Industry, B 19, « Rolle général des bastiments de mer (...) », around 1687 (many thanks to Gilbert Buti for having provided me with this source).

${ }^{24}$ ADBdR, Accoules Parish register, marriage on 3rd August 1669.

${ }^{25}$ Loans of 174 livres tournois for L'Espérance voyage in 1667 and 177 livres tournois for Le Saint-Cyprien voyage in 1668 (ADBdR, 359 E 115 et 117, acts of 11th Nov, 1667 and 2nd Jan, 1669, fol. $903 \mathrm{v}^{\circ}$ and fol. 2).
} 
father, Guillaume, was already in charge of selling worked corals in Smyrna for François Garnier up until $1670^{26}$.

François Tiran settled in Smyrna in January 1679 and remained there until 1684. During his first year of residence in the Anatolian port, he received four shipments of coral in the form of round beads and olivettes from François Garnier, which he sold in three sales between 1679 and 1681, before falling out definitively with his cousin for the reasons presented below. Thus, this article examines the elements of these three sales through the many deals described in the fifteen letters sent by François Tiran to François Garnier, and kept in the archives of the Marseilles Commercial Court. This documentation, combined with notarial deeds, made it possible to gain an insight into the mechanisms of the coral trade in Smyrna at the end of the 17th century.

Table 1: shipments of worked coral from François Garnier to François Tiran in $1679^{27}$

\begin{tabular}{|c|c|c|c|}
\hline Merchandise & Weight & Shipping vessel & Date of reception \\
\hline $\begin{array}{c}\text { Two packets of } \\
\text { round beads }\end{array}$ & $?$ & $\begin{array}{c}\text { Le Saint-Cyprien, cap. } \\
\text { Serry from Toulon }\end{array}$ & January 1679 \\
\hline $\begin{array}{c}\text { Four packets of } \\
\text { olivettes }\end{array}$ & $\begin{array}{c}27 \text { pounds of } 100 \\
\text { Smyrna drachmas } \\
(8.517 \mathrm{kgs})\end{array}$ & $\begin{array}{c}\text { Notre Dame de Grâce, } \\
\text { cap. Gazille from } \\
\text { Marseilles }\end{array}$ & July 1679 \\
\hline $\begin{array}{c}\text { A box of round } \\
\text { beads }\end{array}$ & \multirow{2}{*}{$\begin{array}{c}\text { Ae Saint-Joseph, cap. } \\
\text { Henry from Marseilles }\end{array}$} & Autumn 1679 \\
\cline { 1 - 4 } beads
\end{tabular}

\section{Clients and competition}

In Smyrna, worked coral was a niche product insofar as it was linked to a specific collection and production area, it targeted a specific clientele, one that was found in the more distant regions of Persia, India and Tibet, and it concerned the particular market segment of necklaces, bracelets and prayer beads. So, did this form a market niche? The number of buyers seemed small and a certain competition was at work on the sellers' side. Due to its competitive structure and the measured number of players involved, the Smyrna coral market resembled a bilateral oligopoly.

\section{Armenian buyers}

So who did François Garnier and François Tiran sell coral to in Smyrna? The letters sent by François Tiran do not give precise names, but do however, provide

\footnotetext{
${ }^{26}$ ADBdR, 2 B 804, Guillaume Tiran's post-death inventory. 5.5 pounds weight of Marseille of coral beads in chains and rosaries were found in his belongings, wrapped up in paper.

27 ADBdR, 9 B 175, the Tiran \& Rampal company's correspondence register (now no longer cited), letters from François Tiran to François Garnier dated 22nd Jan, 21st July and 10th Nov 1679.
} 
information on the buyers' profiles. Moreover, the correspondence gives us the details of the negotiations regarding the first shipment, which was to "an Armenian merchant" who showed an interest in the merchandise in January $1679^{28}$, and "who is soon to leave for Persia by caravan". However, no transaction took place in the end. Three months later, François Tiran informed François Garnier of a new sales opportunity: "Some Armenians came to see your corals" 29 ", and it was with one of them that the deal was concluded, after repeated discussions between the end of April and July $1679^{30}$. While this example alone cannot be used to establish any generalisation about the Marseilles coral merchants' clientele in Smyrna, it seems to confirm the elements available in the bibliography of Eurasian trade at the end of the 17th century: the buyer was first and foremost an Armenian merchant from Persia using the caravan routes from Isfahan.

Within the coral trade, Smyrna was more a place of transhipment and exchanges between merchants than a place of consumption. It was indeed the meeting place for Marseilles merchants and merchants likely to take the worked corals to their final destinations. For the three sales that François Tiran had to manage on behalf of François Garnier, he seemed totally obsessed with the comings and goings of the Persian caravans ${ }^{31}$. Armenians were omnipresent there, and so for the 20 caravans coming from Persia to Smyrna between August 1674 and November 1676, the caravan-bachi, (the merchant elected by his peers to lead the convoy), was six times an Armenian ${ }^{32}$. In the 1660s, the Capucin Father Raphael du Mans highlighted how important this community's merchants' role was in the trade between the Ports of the Levant and Persia, and noted that coral

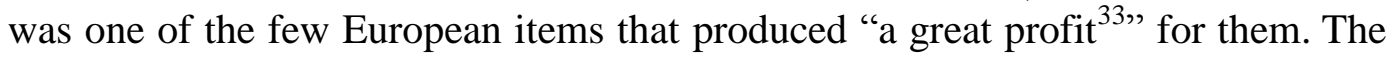
traders of this nation, whose most efficient network started from New Julfa (a suburb of Isfahan) in the early seventeenth century ${ }^{34}$, were not content to only supply the trade between Smyrna and Isfahan, and subsequently expanded it. As soon as the coral arrived in the capital of the Safavid Empire, its journey branched off in two directions. Either it went to Bandar Abbas, sometimes in considerable proportions $^{35}$, and found its outlets in the Indian Ocean, particularly on the Gujarati port in Surat, or it followed the road from Kandahar to Nepal, Bhutan, and especially Tibet. The Armenians remained the undisputed masters of the coral

\footnotetext{
${ }^{28}$ Letter from Tiran to Garnier dated 21st Jan, 1679.

${ }^{29}$ Letter from Tiran to Garnier dated 29th April 1679.

${ }^{30}$ Letters from Tiran to Garnier dated 29th April, 12th June, and 21st July 1679.

${ }^{31}$ Letters from Tiran to Garnier dated 22nd Jan 1679, 13th April 1680 and 23rd August 1680.

32 The Ministry of Foreign Affairs Archives of France, political correspondence, Turkey, Vol. XI, fol. 197 et seq., « Caravanes de Perse » (report written around 1676).

${ }^{33} \mathrm{BNF}, \mathrm{ms}$. fr. 5.632 : «Estat de la Perse » (1660), fol. $62 \mathrm{v}$.

${ }^{34}$ Sebouh D. Aslanian, From the Indian Ocean to the Mediterranean: Circulation and the Global Trade Networks of American Merchants from New Julfa, Isfahan, 1605-1747, Berkeley, The University of California Press, 2011.

${ }^{35}$ In 1695-1696, Armenians held 100,000 écus worth of coral in Bandar Abbas port, ANOM, COL C 2 64, Martin's letter from Surat dated 25th July 1696.
} 
trade to Lhasa, and exchanged this commodity most frequently for musk; at least up until $1720^{36}$.

Coral was a desired commodity due to its intrinsic, cultural and market value, and was thus an important trading product for Armenians to exchange with Europeans and other Asians. Moreover, it was rare and had lucrative outlets. Coral was also used to barter. It was the commodity that Armenians proposed when they sourced products from other eastern merchants and accepted when they sold their goods to Europeans.

\section{Competition between Marseilles traders and Armenians}

So as to sell François Garnier's goods in Smyrna, François Tiran had to compete with other commission agents acting on behalf of other Marseilles coral merchants who, without exception, were all seeking to sell in the main Levant port. Thus, around 1680, the Sallade brothers were working with François Rémuzat and Jacques Seguin, while François Meistre chose Luc Martin and Pierre Chaulier $^{37}$. Competition was not only confined to the profession. Coral was perceived as an opportunity for all Marseilles merchants involved in Levantine trade and who therefore did not hesitate to invest large sums when products were financially attractive. Thus, in April 1680, François Tiran raised his concerns with François Garnier regarding these commercial practices: "A certain Chaine (...) brought 1,200 piastres worth of coral that he was obliged to leave in the hands of Mr Chaulier and Mr Martin (...) we were assured that it was extremely beautiful (...) We are unhappy that such a considerable part of it is here ${ }^{38, "}$.

The competition from Marseilles was also due to the large number of Armenians who had settled in Provence as from $1669^{39}$. These traders, mainly from New Julfa, were aware of this product's profitability and thus went into action so as to gain market share in Smyrna. For instance, in 1680, Baba de Serquis sent his representative Marcara de Coripjean from Marseilles to Smyrna with "26 livres [weight of Marseilles] of coral beads from Genoa (...) two pieces of coral weighing 68 dragmes (...) 8 large and small coral chains weighing 67 dragmes (...) and a coral chain decorated with silver ${ }^{40}$. . Another example is Melchion de Nazar, consul of the Armenian Nation of Marseilles, who regularly sent coral shipments to his Marseilles commission agents, Charles Guion in the early 1670s, and then François Grimaud. The coral trade formed intercultural partnerships whose reliability was guaranteed by the Phocaean commercial courts

\footnotetext{
${ }^{36}$ Luce Boulnois, «Musc, or et laine : le commerce à Lhasa au XVII ${ }^{\mathrm{e}}$ siècle », dans Françoise Pommaret (dir.), Lhasa, lieu du divin. La capitale des Dalaï lama au XVII siècle, Paris, Oziane, 1998, p. 180-188.

${ }^{37}$ ADBdR, 9 B 117, Admiralty of Provence and the Levant Seas, audience dated 14th June 1680 and $364 \mathrm{E} 286$, fol. $170 \mathrm{v}^{\circ}$, act dated 28th March 1681.

${ }^{38}$ Letter from Tiran to Garnier dated 3rd April 1679.

${ }^{39}$ Olivier Raveux, «Entre réseau communautaire intercontinental et intégration locale : la colonie marseillaise des marchands arméniens de la Nouvelle-Djoulfa (Ispahan), 1669-1695 », Revue d'Histoire Moderne et Contemporaine, 59-1, 2012, p. 81-100.

${ }^{40}$ ADBdR, 13 B 43, Marseille Commercial Court, Paul de Serquis v Marcara de Coripjean, report dated 9th April 1682.
} 
such as the Commercial Court of Marseilles and the Admiralty of Provence and the Levant Seas.

Table n 2: Charles Guion and François Grimaud's various coral business deals in Smyrna on behalf of the Marseilles Armenian merchant, Melchion de Nazar $(1670-1678)^{41}$

\begin{tabular}{|c|c|c|c|}
\hline Merchandise & $\begin{array}{c}\text { Commission } \\
\text { agent }\end{array}$ & Date of reception & $\begin{array}{c}\text { Date of sale/on-site } \\
\text { bartering }\end{array}$ \\
\hline $\begin{array}{c}5.600 \text { drachmes of worked coral } \\
(17.66 \mathrm{kgs})\end{array}$ & Charles Guion & Autumn 1670 & Spring 1671 \\
\hline $\begin{array}{c}69 \text { chequis } \text { of worked coral } \\
(26.12 \mathrm{kgs})\end{array}$ & Charles Guion & Autumn 1672 & Summer 1673 \\
\hline $\begin{array}{c}43,5 \text { chequis } \text { of worked coral } \\
(16.47 \mathrm{kgs})\end{array}$ & Charles Guion & Autumn 1672 & Summer 1673 \\
\hline $\begin{array}{c}1 \text { chest of worked coral } \\
\text { weight } \text { unknown }\end{array}$ & François Grimaud & $?$ & Beginning of 1678 \\
\hline
\end{tabular}

This Armenian competition was not limited to Marseilles and was also found in Italy, in the main coral-related cities, such as Trapani, Naples, Genoa and Livorno. The quantities of coral sent to Smyrna from these ports seem to be significant. Thus, during the summer of 1672, the Notre Dame de Montanègre vessel left Livorno for the Anatolian coast transporting the Armenian merchant from New Julfa, Boghos de Jacob's coral, namely 15 packages of round beads weighing 86 pounds and 8 ounces weight of Marseilles, and his colleague, Jegh Nazar de Fodan's merchandise, consisting of two boxes filled with raw pieces of coral and weighing a total of 7 quintals and 47 pounds of Marseilles ${ }^{42}$. In September 1676, a large part of a 3,000 pounds weight of Tuscany of a very beautiful coloured coral extracted from a deposit recently discovered in the seas of Livorno was purchased by local Armenian merchants, who shipped it to Persia ${ }^{43}$. While Sephardic Jews tended to monopolise the coral trade to Asia through London and the ocean at the end of the 17 th century ${ }^{44}$, the Armenians established themselves in the eastern Mediterranean as the main suppliers of intra-Asian caravans.

Thus, François Tiran had to operate in a market made difficult by an irregular clientele and omnipresent competition. Dependent on the rhythm of the caravans and poorly informed about the global characteristics of supply and demand, the

\footnotetext{
${ }^{41}$ ADBdR, 9 B 155, ruling of the Admiralty of Marseilles dated 26th September. 1679; 362 E 124, notary Louis Bezaudin, fol. 985 et 13 B 50, the Commercial Court of Marseilles' rulings on 17 th October, 1674, in the case of Melchion de Nazar v Charles Guion. The 120 drachmes chequis of Smyrna was worth 378.56 grams.

${ }^{42}$ ADBdR, 356 E 449, fo. $715 \mathrm{v}^{\circ}$, act of 17 th July 1673

43 «Estratto di una lettera del M. Rever. Padre F. Enrico de Noris (...) in cui gli dà ragguaglio della nuova pesca di corallo ritruovata nelle continenze del porto di Livorno », dans Il giornale de letterati per tutto l'anno 1676, Rome, 1676, p. 49-51.

${ }^{44}$ Gedalia Yogev, Diamonds..., op. cit.; Walter J. Fischel, "The Jewish Merchant-Colony in Madras during the $17^{\text {th }}$ and $18^{\text {th }}$ Centuries: A Contribution to the Economic and Social History of the Jews in India", Journal of Economic and Social History of Orient, vol.3/1-2, 1960, p. 78-195.
} 
Marseilles broker owed his success to his ability to find buyers likely to trade the oriental goods he was seeking for corals of variable quality.

\section{The "wheels of commerce" and profits}

Finding the buyer, the right price, the best merchandise to take in return, and differentiating oneself from the competition made selling to Smyrna a matter of patience, especially as the products could take several months to sell. Everything depended on the methods of "bartering", which determined part of the profit made by the coral merchant. The commission agent and his client often disagreed on the transactions. François Tiran seemed driven by the desire to sell, albeit with measured requirements, so as to receive his commission in the shortest possible time, while François Garnier preferred to wait in order to obtain the optimal conditions for future gains.

\section{Bartering}

Although the commercial circles of the Enlightenment were "repulsed" 45 by bartering, the latter was one of the basic elements of transactions between the Marseilles traders and the Orientals in Smyrna in the 17th century. As coral was one of the most prized commodities for Asians when it was of good colour and quality, it was traded against the most sought-after products by Europeans in the Ports of the Levant. These goods were ranked in a well-defined preferential order, with Persian silk being the most desired. However, the commission agent, in his absence or when the coral was of sub-standard quality, had to lower his expectations and hopes. Hence, his interest turned to printed and painted cottons from Persia, "the most liquid commodity after silk ${ }^{46, ", ~ o r ~ t h o s e ~ p r o d u c e d ~ i n ~ S i r o n j ~}$ in India and exported to the Ports of the Levant passing through Surat and Bandar Abbas, and white Indian muslins (caïmacanis and other Bengal cambrésines). Finally, the least desirable were goods such as chevron wool, a last resort in case of difficult situations. Nevertheless, on very rare occasions, unexpected opportunities presented themselves. For example, François Tiran once tried to negotiate and barter coral for lapis lazuli ${ }^{47}$.

The success of bartering depended on several parametres. Essentially, it was influenced by the presence of oriental goods in Smyrna. Thus, if François Tiran was unable to exchange any of his corals for silk it was because there was none, to his great despair ${ }^{48}$. A successful transaction was also linked to the type and quality of the coral on sale. Tiran complained several times about his correspondent's shipments, in particular about four olivette coral packages, "whose shape was not

\footnotetext{
${ }^{45}$ The term was used in the correspondence between the trading firm Roux and Garavaque and its representative in Smyrna, in 1764 (Archives from the Marseilles Chambre of Commerce, L IX/739, letter dated 11th September 1764. Many thanks to Sébastien Lupo for having provided me with this source).

${ }^{46}$ Letter from Tiran to J. F. Fresquière on 5th August 1679.

${ }^{47}$ Letter from Tiran to Garnier on 3rd April 1680.

${ }^{48}$ Letters from Tiran to Garnier on 5th August 1679, 20th February, and 13th April 1680.
} 
held in great esteem" and whose "gaps were heavily loaded with wax, thus making them difficult to sell ${ }^{49}$ ". Nevertheless, the commission agent's correspondence sometimes made it difficult to differentiate between what was a real complaint and what was an apology intended to hide a mistake or a liberty taken in relation to a client's order. It remains nonetheless true that coral beads of good colour and quality remained the best selling commodity in Smyrna around 1680. Finally, good bartering depended on the amount of silver coins allocated to the transaction.

Bartering without any monetary component seemed to be rare in Smyrna. We know how important silver was for Asian economies in the early modern period ${ }^{50}$, and Europeans therefore most often had to include a quantity of silver coins in the transaction. This is why François Garnier sent François Tiran 200 piastres in the summer of 1679 so he could acquire printed and painted cottons from an Armenian. Half of them were bought with money, the other half bartered with coral. Without receiving these piastres from his client, the commission agent sometimes had to borrow from a colleague so as to sell the goods ${ }^{51}$. And this is exactly what François Tiran did in the spring of 1681. He borrowed 200 piastres from Antoine Simon, a merchant from Marseilles and agent of the Knights of the Order of Malta in Smyrna, at an interest rate of $15 \%$. This practice was unpopular with the merchants as it obviously ate into their future profits. It was thus this loan that François Tiran had decided to take out without François Garnier's assent that sealed the final dispute between the two men in $1681^{53}$. The latter reveals the pitfalls that could badly damage the client/commission agent's good working relationship, and especially highlights the difficulty of circulating information and instructions between the ordering merchant in Marseilles and his representative in Smyrna with sufficient speed $^{54}$.

\section{Double-trigger profits to be built over time}

So, what profits did the coral trade in Smyrna generate? Some data found in the archives and provided by the bibliography helped us understand. Although we do not have any details concerning François Garnier's purchases of round coral beads and olivettes, we do however know what was charged for the raw materials in the main workplaces in the western Mediterranean basin. As shown in the following table, worked coral was traded according to its types and qualities in Marseilles, Cassis, Genoa and Livorno with prices ranging from 16 to 20 livres tournois per pound weight of Marseilles.

\footnotetext{
${ }^{49}$ Letters from Tiran to Garnier on 29th April and 12th June 1679.

50 Carlos Marichal, «La piastre ou real de huit en Espagne et en Amérique : une monnaie universelle $\left(\mathrm{XVI}^{\mathrm{e}}-\mathrm{XVIII}^{\mathrm{e}}\right.$ siècles) », Revue Européenne des Sciences Sociales, XLV, 2007, p. 107121.

${ }^{51}$ The goods were mortgaged and the loan was repaid on returning from the trip.

${ }^{38}$ Letter from Tiran to Garnier dated 8th June 1681.

${ }^{53}$ Letter from Tiran to Garnier dated 10th Dec 1681. François Garnier considered the interest rates too high for a product he thought difficult to sell in Marseilles.

${ }^{54}$ A Marseilles-Smyrna return correspondence took at least two to three months.
} 
Table n⿳3 3 : value of worked coral in Provence, Tuscany and Liguria (1672-1680) ${ }^{55}$

\begin{tabular}{|c|c|c|c|c|}
\hline Type & Place & Date & Sellers/Buyers & Price \\
\hline Olivettes & Marseilles & 1672 & $\begin{array}{l}\text { The Sallade brothers to } \\
\text { G. Truilhard }\end{array}$ & $\begin{array}{l}20 \text { livres tournois the pound weight } \\
\text { of Marseilles }\end{array}$ \\
\hline$?$ & Marseilles & 1673 & $\begin{array}{l}\text { P. Géraud to G. } \\
\text { Truilhard }\end{array}$ & $\begin{array}{c}17 \text { livres tournois the pound weight } \\
\text { of Marseilles }\end{array}$ \\
\hline Beads & Genoa & 1674 & $\begin{array}{l}\text { Censal of Genoa to L. } \\
\text { Truilhard from } \\
\text { Marseilles }\end{array}$ & $\begin{array}{l}20 \text { livres tournois the pound weight } \\
\text { of Marseilles }\end{array}$ \\
\hline$?$ & Livorno & 1675 & $\begin{array}{l}\text { Muslim slaves to the } \\
\text { Jewish merchant } \\
\text { Villareal }\end{array}$ & $\begin{array}{c}5 \text { to } 5,5 \text { piastres the pound weight } \\
\text { of Livorno ( } 339.55 \text { grams), thus } 17 \\
\text { to } 19 \text { livres the pound weight of } \\
\text { Marseilles }\end{array}$ \\
\hline Olivettes & Cassis & 1680 & $\begin{array}{l}\text { H. Garnier to G. } \\
\text { Brémond and É. } \\
\quad \text { Maunier }\end{array}$ & $\begin{array}{l}16 \text { livres tournois the pound weight } \\
\text { of Marseilles }\end{array}$ \\
\hline
\end{tabular}

In Smyrna, François Tiran sold François Garnier's products at prices ranging from 10 to 25 piastres la livre for 100 local drachmas, or about 36 to 90 livres tournois the pound weight of Marseilles ${ }^{56}$. Price differences were justified by the quality of the coral and the type of transaction. Thus, olivettes, not in great demand in Smyrna around 1680 and used solely for bartering, devalued the price of the coral, while quality round beads combined with silver coins produced much better results. So, could coral triple or quadruple its original price? Shipping costs, Smyrna's taxation, François Tiran's commission, and the higher price of bartered Asian goods cut into the profits ${ }^{57}$. However, with such a large starting margin, there was no doubt that it would remain significant in a business deal lasting between six months and a year. Moreover, business was far from over.

The sale of coral enabled François Garnier to buy Asian goods that were later sold in Marseilles, Europe or elsewhere. Once in Marseilles, Persian silk could reach Lyons where it was sold to local manufacturers. As for the printed and painted cottons from Sironj, it was possible that they found their way to the Beaucaire Fair, as François Tiran suggested to François Garnier in August $1680^{58}$. The Persian chintzes were likely to find more distant destinations, and the following example gives us an insight into what profits François Garnier made. In 1684, after a sale of corals in the Levant, the merchant from Marseilles used the printed and painted cottons from Persia that his commission agent had received in exchange for part of a bottomry loan for an undertaking to the Americas. We are

\footnotetext{
${ }^{55}$ ADBdR, 406 E 89, act dated 12th March 1680, fol. $113 \mathrm{v}^{\circ}$; 39 E 53, the Marseilles merchant Truilhard's ledger (1672-1674).

${ }^{56}$ Other sales attest to this range of values: for example, in the autumn of 1677, the merchant of Marseilles from New Julfa Melchion de Nazar ordered François Grimaud, his commission agent in Smyrna, to sell his coral beads for a price of 26 piastres (78 livres tournois) per pound weight of Marseilles (ADBdR, 9 B 155, the case of François Grimaud/Melchion de Nazar, fol. 1.079 et seq., 1.115 et seq).

57 Commission was generally at two percent in the Ports of the Levant, both on entering and leaving.

${ }^{58}$ Letter from Tiran to Garnier dated 23rd August 1680.
} 
aware of the conditions of this bottomry loan ${ }^{59}$. The debtor, André Audibert, a merchant from La Seyne, dispatched his goods on the Saint-Joseph and sold them in Cayenne and on the islands of Santo Domingo and La Tortue. He promised that on his return, he would give back the value of the printed and painted cottons plus $30 \%$ interest. In this case of a bottomry loan for goods being shipped to the Americas, the time frame to make profits was at best one year for a straightforward trip. Therefore patience and an understanding of the activity were both prerequisites of this business. If François Garnier was unable to negotiate directly with distant Asia, the reason is to be found more in his inability to integrate the ocean networks that would allow this type of trade rather than in his incapacity to bear the immobilisation of capital over time.

$* * *$

Although only a simple link in the broad circulation networks, although limited by the Marseilles shipping trade's radius of activity, although developing rare mobilities, François Garnier founded his coral business in a world of broad horizons and opportunities, between the western basin of the Mediterranean, the near and far East, and throughout Europe and the Americas. Examining this Marseilles merchant's business in Smyrna does not aim to highlight the Mediterranean region's resilience in the face of transatlantic competition. François Garnier also exported corals to Lisbon and Cadiz, which later spread to Goa and Vera Cruz. If observed from the main Levantine ports, this merchant's trade bore witness to the opening of Marseilles and the Mediterranean to the world during the 17th century. This study of some of the coral sales in Smyrna also brings to the fore the great variety of links and means of the movement of goods at work during the globalisation of the early modern period and underlines the impact of the products' particularity on the strategies of those who traded them and on the construction of the networks that enabled them to travel.

${ }^{59}$ ADBdR, 359 E 126, fol. 622, act of 27th March 1684. 